\title{
Determinants of Labour Efficiency in Nigeria: A Cross Company Study of Manufacturing Firms
}

\author{
Onwuchekwa Faith Chidi, Ph.D \\ Ohachosim Celestine Ikem, ACA
}

\begin{abstract}
One great challenge facing the millennium manager in the present competitive business atmosphere is to determine how to make the workforce more efficient. Sequel to this, this study tries to identify factors that determine the efficiency of labour in Nigeria. It applied Ordinary Least Squares (OLS) on a log-linear multiple regression models specified for the purpose of this investigation. The paneled cross-company data is sort from the annual reports and accounts, as well as, from interviews with personnel managers of selected manufacturing firms. The analyses revealed that wage and educational attainment are more than any other factors, the determinants of labour efficiency in Nigeria. The study suggests that manufacturing companies should pay their workers efficient-wages and encourage them to acquire more knowledge through study leaves, seminars and both domestic and oversea trainings.
\end{abstract}

Keywords: labour efficiency, labour productivity, efficiency- wages

\section{INTRODUCTION}

\subsection{Backgrounds}

Labour represents human effort towards production (Bhatia, 1978). Adam Smith in his time recognized the indispensable nature of labour towards production. For him labour was the first price, the original purchasemoney that was paid for all things. In his opinion, it was not by gold or silver, but by labour that all wealth of the world was originally purchased. The views such as the one by Adam Smith have propelled the overwhelming interests witnessed in the issues concerning labour management.

Today, disciplines in social and management sciences, particularly Human Resources Management (HRM) have concentrated on studies to accelerating the efficiency of labour towards production. Labour efficiency is the ratio between the actual output produced and the standard output. It has to do with the measurement of how good a body shop is keeping its technicians busy on productive tasks. Labour efficiency relates to labour productivity in that the efficiency of labour determines its productive ability. Labour productivity itself measures the rate of output per worker in relation to the set standard or expected output. The increase in interests in the efficiency of labour is motivated by the need to bring down the unit costs of products of firms (Fallahi, Sojoodi and Salannia, 2011). With increasing globalization and expansion of competition in industrial products, labour productivity more than before has become determining factor in the competitiveness of industries in domestic and foreign markets (Fellahi, Sojoodi and Salannia, 2011). They expressed the fact that high labour productivity means lower per unit cost and, therefore, ability of the firm to match prices on the global markets. It is because of the fact that prices of products depend largely on cost of production and labour cost is an important component of production costs, labour efficiency which encompasses labour productivity has become a focal point for the millennium managers.

The question of what enhances the efficiency of labour must be answered by the $21^{\text {st }}$ century managers who must thrive in the world's stiff competition resulting from the world becoming a global village. Beginning with wages as the reward for labour, other factors; such as research and development (R\&D), level of information technology (IT), export intensity of the firm, the size of the firm, training and education of workforce have been considered determining factors of labour productivity (Fellahi, Sojoodi and Salannia, 2011). The effect of new technology is also put into consideration but this is the result of the availability of research and development department (R\&D). The precision with which these factors are determined goes a long way to say how successful a firm will be. It is for this reason that these factors are often weighed in relations to Profit before tax (PBT) and in some cases it is evaluated in relation to return on equity.

\subsection{The Problem}

It is a known fact that products of Nigerian origin seldom find its feet in the world market. This is the major reason for the shortage in foreign exchange. One and only foreign exchange earner for Nigeria remain crude oil which is not a match for the massive importation of general goods into Nigeria's economy. The fact being that Nigeria's home made goods are costly when compared with foreign products in both local and international market. Despite the abundant human and material resources, goods/services can still not be produced at lower costs to face the global competition. This weakness is as a result of poor efficiency of the Nigerian labour force. To re-direct the trend, the need to identify the factors that determine the efficiency of labour in Nigeria becomes of paramount importance. In addition, with the articulation of vision20: 2020 which targets to catapult Nigeria 
into the league of the first global 20 economies (Eneh, 2011) and the renewed agenda of the federal government of Nigeria to rehabilitate the ailing country's economy through diversification, labour efficiency must be given special attention. This is because it would be difficult to make any improvements in any country's well-being (talk more of joining first global 20 economies) without efficient labour force. Studies which tried to determine the efficiency of labour with particular reference to Nigeria's manufacturing environment are substantially lacking in the present. It is this gap that this study attempted to fill.

Consequent upon the highlighted problem, the general objective of this study is to evaluate the determinants of the efficiency of labour in Nigeria. Specifically, the study identified factors, in order of relevance, that affect labour efficiency and made recommendations on the appropriate improvement needs of labour for profitable utilization of Nigeria's labour force.

\subsection{Literature review}

\subsection{Theoretical Review}

Theories relating to labour efficiency started with the articulation of the neo-classical economist, Alfred Marshall. In 1890, Marshall's model associated labour efficiency with competitive ability. Marshall's model followed the view of the classical economists which relates labour efficiency to the quantity of labour required to produce a commodity and to bring it to the market (Stankeviciene, Liucvaitiene and Simelyte, 2009). This view has not varied significantly even with emerging studies as efficiency of labour is still measured in relation to quantity produced. The first factor considered in determining labour efficiency is the general and specific ability of the labour force. It is this factor that requires a labourer to be trained. For this reason the level of education of a worker is considered as a crucial determinant of its efficiency at work. General and specific ability is also built on the job, as well as, through continuous staff training. Another prominent determinant of labour efficiency is the competitiveness of the market structure. Marshall (1890) explained that market structure and competitiveness affect the productive efficiency of labour. Labour efficiency goes up with increase in market pressures. To buttress on this factor, Liebenestein (1966) explained that efficiency depends on location of firms than on the worker's ability. With this submission, emphasis was been laid on the working conditions of workers which the location of firm remained a crucial factor. There are theories supporting the view that efficiency of workers depends on the level of advancement of the country where the firm is located. On this, Farrell and Fieldhouse (1962) shared the view that if a company is located in the developing countries, the efficiency of its workers would depend on the industrial development than on the market structure.

Labour Efficiency: its relation to productivity and effectiveness.

Labour is productive only if it is efficient and effective. General systems theory defines effectiveness as a degree to which the actual outputs of the system correspond to their desired outputs or planned outputs. The same theory defines efficiency as the ratio of actual outputs to actual inputs. Relying on these definitions provided by the general system theory, productivity is a combination of effectiveness and efficiency (Bardhan, Cooper \& Kumbhakar, 1998; Carter, 1990). Relevant formulas are:

Effectiveness $=\underline{\text { Actual Output }(\mathrm{U})}$ Desired Outputs (U*)

$$
\begin{gathered}
\text { Efficiency }=\underline{\text { Actual Output (U) }} \\
\text { Actual Input (I) }
\end{gathered}
$$

In relation to the above, labour productivity is measured by the ratio of physical units which were produced or sold for what was required to produce or sell (measured in physical units or constant prices). Labour productivity is defined as the ratio of production units that is output divided by input (Bradford, 2001). Productivity varies according to differences in production technology, differences in the production process efficiency and differences in the environment where production occurs. The difference occurs when the efficiency of a production unit is compared between actual and optimal values of its output and input. The comparison obtains form of the ratio as an actual to maximum potential output is measured from the given input, it obtains form of the ratio as a minimum potential to actual input is required to produce the given output, or a combination of both. Both comparisons, however, define optimal production possibilities in relation to technical efficiency.

The ability of management to measure efficiency and productivity appropriately would enhance effective control of input variables. Management main objectives can be either higher output with the same level of inputs or the same output with fewer inputs. Any of the two attained implies efficiency and no form of efficiency can be achieved, no matter the level of technology or physical capital, with labour in isolation. Therefore, management show much concerned about the factors that affect labour efficiency.

Subsequent models for-efficiency measurement

The neoclassical model offered by Marshall has been useful in measuring efficiency and it is still in use till the present time. Scholars have relied on the Marshall's labour efficiency model to develop a lot of very useful 
models. Koopmans (1951), Debreu (1951) and Farrel (1957) dealt on technical efficiency which became DebreuFarrell Model. These scholars saw technical efficiency as a form of economic efficiency which allocative efficiency was also part. Technical efficiency is defined as the capacity and willingness to produce the maximum possible output from a given bundle of input and technology where as allocative efficiency reflects the ability of the management to use the inputs in optimal proportions considering respective marginal costs. Also prominent in the literature is the Wage Model (1986) and Wage Hours Model (1991) which is associated to motivation theorists. The Wage Model was simply based on motivations for efficiency-wages. The work flow method is another model which measured changes in labour efficiency and was based on the work-hour concept. There are other neoclassical models such as direct labour work hour efficiency model (WHEM) and demonstrated labour efficiency model (DLE) which were suggested by McCally (1990) and both mentioned models are adoptable for Critical Path Method (CPM). Recent researches on efficiency measurement were based on regression analyses. The method provides opportunities for the researcher to investigate the effects of a number of factors (independent variables) on the productivity proxy (dependent variable).

\subsection{Empirical Review}

There are a number of studies of extensive empirical substance on the factors affecting labour productivity. In these studies, the dependent variable was labour productivity and the independent variables were physical capital, health capital, firm size, research and development (R\&D), wage level, ownership status and knowledge capital. We shall review briefly some of these studies.

Berndt, Morrison and Rosenblum (1992) in their study showed a negative effect of ICT equipment on labour productivity in industry level in the United States. Lichtenberg (1993) using data of five hundred firms in the United States showed that increased physical capital in the field of ICT leads to increase in labour productivity. The study of Brynjolfsson and Hitt (1995) confirmed this result. Bernard (1995) conducted a study for Mexico and find out that being an exporter enhances productivity. Corvers (1996) carried out a study on the effects of human capital on both the level and growth of labor productivity in manufacturing sectors in seven Member States of the European Union. The results of this study show that both intermediate and highly-skilled labor had a positive effect on the sectoral labour productivity level. Black and Lynch (1996) used the data of more than 3000 private establishments with more than 20 employees in united state, to study the impact of training on productivity. Their findings show that the level of education has a positive and significant effect on productivity. Huang, Hallan, Peter and Peter (1998) for the industrial sector in China have shown that productivity is affected by wage more than any other factor including human capital. Laurin and Bozec (2001) investigated the effect of firm ownership on productivity and their results show that firms with private ownership have more efficiency. Mühlau and Lindenberg (2003) using statistical data in Japan found that wage has so much influence on productivity. Almeida and Carneiro (2008) carried out a study on the impact of training on organizational productivity by using a firm-level data and their results indicate firm trainings have positive and significant effect on firm productivity. Aggrey, Eliah and Shitundu (2010) in their study utilised firm-level data of African manufacturing firms to investigate the impact of education on productivity. Their analyses revealed that the effect of education and training on labour productivity was positive and significant. Fallahi, Sojoodu and Aslaninia (2011) studied the determinants of labour productivity in Iran's manufacturing firms. The study is cross sectional log-linear regression analyses with labour productivity as the dependent variable and education, capital intensity, research and development (R\&D), status of export, ownership status and wage level as independent variables. Their analyses revealed that all the variables were both significant and possess positive co-efficient. They conclude that these variables contribute significantly to the productivity of labour and therefore, very crucial in determining the efficiency of labour in Iran. Umoru and Yaqub (2013) carried out a study on labour productivity and health capital in Nigeria. The study applied the general method of moments (GMM) methodology in the estimation of the model specified for the estimation of the effects of education and health of workers on productivity. Their findings include that health capital enhances productivity. Their conclusion was that since Nigeria is a labour-intensive country, higher value of labour would be achieved by maintaining healthy workers.

\section{Methodology}

The study applied Ordinary Least Square (OLS) on paneled cross-company data of ten selected manufacturing firms quoted on the Nigerian stock exchange (NSE). Data is sourced from the annual reports and financial statements of the companies for the years 2000 to 2015 and through personal interviews with personnel managers (or designated officials) of the selected companies. To estimate the effects of the specified variables on the efficiency variable, we have taken the differentials ${ }^{1}$ of all the relevant variables (both the dependant and the

\footnotetext{
${ }^{1}$ Note Before: Derivative of all differentials follow the linear order, DATA $2-$ DATA $_{\mathrm{N} 1}=\delta_{1}$ and DATA 1 DATA - DA $_{\mathrm{N}}=\delta_{\mathrm{N}}$. Where DATA 2 represents the figure for the relevant variables in the year two, DATA $\mathrm{N}_{\mathrm{N} 1}$ represents the figure for the relevant variables in year one and the
} 
independent variables).

The study specified a log-linear multiple regressions model. It follows the line of the model specified by Papadogonas and Voulgaries (2005) in Greece and adopted by Fellahi, Sojoodi and Aslaninia (2011) in Iran for the estimation of determinants of labour productivity. The dynamic nature of researches in management sciences requires the combination of absolute variables with dummy variables. This is to be able to capture some qualitative characteristics of the study (Gujarati, 2009). The ten companies selected are largely based on researcher's description. The choice of choosing manufacturing firms for the study is influenced by the fact that manufacturing firms have high tendencies to show the impact of efficient labour force on firm's performance.

The model is specified as follows:

$\operatorname{In} \delta$ PBT $=\alpha_{0}+\alpha_{1} \operatorname{In} \delta(\mathrm{W} / \mathrm{E})+\alpha_{2} \operatorname{In}(\mathrm{R} \& \mathrm{D})+\alpha_{3} \operatorname{In} \delta(\mathrm{W} / \mathrm{M})+\alpha_{4} \operatorname{In}(\mathrm{Szf})+\alpha_{5} \operatorname{InEdu}+\alpha_{6} \operatorname{InExp}+\mu_{0}-----(3)$

Where;

In $\delta$ PBT $=\log$ of differentials of Profit before tax $(\mathrm{PBT})$

$\operatorname{In} \delta(\mathrm{W} / \mathrm{E})=\log$ of differentials of wages or salary over total expenditure.

In $(R \& D)=\log$ of Dummy, the value is 1 if a firm has $R \& D$ unit and 0 if it does not.

In $\delta(\mathrm{W} / \mathrm{M})=\log$ of differentials ratio of women over men of members of the board.

In $\mathrm{SzF}=\log$ of the Dummy for size of firm. It is 1 for firm with international face and it is 0 for

firms without international face.

In Edu $=\log$ of education ratings for minimum entry into management positions.

School Certificate $=0$

Degree Certificate $=1$

School Certificate Plus Professional Qualification $=2$

Degree Certificate Plus Professional Qualification $=3$

In Exp $=\log$ of experience ratings for minimum entry into management positions. The ratings are as follows;

$0-5=0$

$5-10=1$

$10-15=2$

$15-20=3$

$20-25=4$

$25-30=5$

$\mu_{0}$ is the stochastic error term.

$4 \quad$ Presentation of Results and Discussion

The model specified above has been estimated and the result is stated as in table II below

TABLE II: REGRESSION RESULT

VARIABLE COEFFICIENT T-STATISTIC

$\delta(\mathrm{W} / \mathrm{E}) \quad 5.660359$

$\delta(\mathrm{W} / \mathrm{M} \quad-451.9143 \quad-1.691870$

$\begin{array}{lll}\text { R\&D } & 42.38288 & 0.274682\end{array}$

SZF $\quad-226.9496 \quad-2.503505$

$\begin{array}{lll}\text { EDU } & 126.3134 & 1.786934\end{array}$

$\begin{array}{lll}\text { EXP } & 70.75256 & 0.474744\end{array}$

$\mathrm{R}-$ Squared $=0.883988$

Adjusted R - Squared $=0.738972$

Durbin-Watson $=2.349060$

F-Statistic $=6.095810$

The regression results shown above revealed that only differentials of wages over total expenditure $\delta(\mathrm{W} / \mathrm{E})$ and education (edu) are significant in the model and they have positive coefficients with differentials of profit before tax (PBT). Research and development (R\&D) and experience (EXP) over the years have positive coefficients but they are not significant in the model. Differentials of women to men ratio has negative coefficient and it is also non-significant in the model. It does not make any difference whether a worker is a

relevant differentials figures are; $\delta_{1}, \delta_{\mathrm{N}} \ldots$. 
woman or man in any work place in Nigeria. The size of the firm (SZF) has negative coefficient and it is also non-significant in the model. This means that it does not make any difference whether a firm is exporting or not. The Nigerian market is so large and has not been explored to the brim so whether a firm is exporting or not cannot make the workers to be more efficient. R-squared and Adjusted R-Squared show that all the variables join together have strong relationship with the performance variables-differentials of profit before tax $(\delta \mathrm{PBT})$. The Fstatistics show that all the variables are collectively significant. The value of Durbin Watson shows the absence of autocorrelations.

\subsection{CONCLUSION}

Our analyses show that unlike works undertaken in the advance countries of the world, wages and level of education are more relevant in determining the efficiency of labour in Nigeria. The result is not surprising because of the level of development of Nigerian workforce. It could be seen that wages and salaries derive the Nigerian workforce to effectiveness. Evidence is the overwhelming minimum wage charade and the incessant demand for higher wage by the Nigeria labour congress (NUC) in the country. Nigerian workers, more than any, suffers the money-illusion. Every other factor identified in this work is relevant when applied in company of other factors but they are individually impotent in determining the efficiency of labour in Nigeria. Manufacturing firms in Nigeria do not make adequate utilization of the R\&D unit; this is the reason for the negative coefficient which the R\&D possessed. Workers in Nigeria respond more sharply to incentives that affects them positively and personally. It is certain that where efficient - wage ${ }^{1}$, which is the adequate reward for workers' efforts, enhance their disposition to work, education and training ${ }^{2}$ improves on their skills in the work. The findings of this study agree with those of some of the studies reviewed above especially; Muhlau and lindenberg (2003), Aggrey, Eliah and Shitundu (2010) and Fallahi, Sojoodu and Aslaninia (2011).

\subsection{Recommendation}

Consequent upon the conclusions reached in this study, we make the following recommendations. Companies in Nigeria should motivate their workers by paying them efficient wages. Companies should encourage their workers to acquire and update knowledge about their work. This is because wage and education of workers are found most effective in enhancing efficiency in Nigerian workers. This can be achieved by organizing trainings and workshop as well as higher education (in the form of study leaves). It is also important that manufacturing firms in Nigeria should make productive use of their Research and Development units. This will help to development new technologies that can make the labour force more efficient.

\section{REFERENCE}

Aggrey, N. L., Eliah, M. \& J. Shitundu (2010). Human capital and labour productivity in East African manufacturing firms. Current research journal of economic theory, 2(2), 48-54.

Almedia, R. \& Carnciro P. (2009). The return on firm investment in human capital, Labour Economics. 16(1), 97-106.

Annual Reports of companies-Nigeria Stock Exchange, Accessed February 6 2013. http:// investingmafrica.net/wp stock market.

Bardhan, I., Cooper, S.C. \& Kumblakar, S. C. (1989). A simulation of joint uses of Data envelopment analysis and statistical regression for production function estimation and Efficiency Evaluation, Journal of productivity Analysis, 9(3), 249-278.

Bartel, A.P. \& Lichleng F. R. (1987). The comparative advantages of complementing new Technology. Review of economics and statistics, 69(1), 1-11

Bernard, A. B. (1995). Exporters and trade liberalization in Mexico: production structure and performance, MIT mimeo February.

Berndt, E. R, Morrison, C. J. \& Rosenblum, L. S. (1992). High-tech capital, economic performance and labour composition in U.S. manufacturing industries: an Exploratory analysis. MIT working paper, 341AEFA.

Bhatia, H. L. (1978). History of economic thought, New Delhi: Vikas publishing House PVT Ltd.

Black, S. \& Lynch, L. (1996). Human-capital investments and productivity. American economic review, 86(2), 263-267.

Bradford, J.O. (2001). Macroeconomics Burg Birgs IL: McGrow-Hill.

Brynjolfson, E. \& Hitt, L. (1995). Information technology as a factor of production: the Role of difference among firms. Economics, innovation and new technology, 3,183-199.

Carter, J.T. (1990). Are Wages too low? Empirical implication of efficiency wage model. Southern economic journal, 56(3), 594.

\footnotetext{
${ }^{1}$ Efficient-wage may involve all contributions of employee that make the employee financially well-off.

${ }^{2}$ Education and training may involve the activities of the employer that improve the employee's knowledge and skills of job.
} 
Corvers, F. (1997). The impact of human capital on labour productivity in manufacturing sectors of the European Union. Applied Economics, 29(8): 975-987.

Debrea, G. (1952).The Coefficient of resource utilization", Econometrica, 19(3). 273-292

Eneh, C. O. (2011). Nigeria's Vission 20:2020- issues, challenges and implication for development management. Asian journal of rural development, 1(1), 21-40.

Falhahi, F., Sojoodi, S. \& Aslaninia, N.M (2011). Determinants of labour productivity in Iran's manufacturing firms: with emphasis on labour education and farming, paper presented at International Conference on Applied Economics (ICOAE), 169 - 178.

Farrell, M.J. \& Field house (1962). Estimating efficient production under increasing return to scale. Journal of royal statistical society, 125, 252-267.

Gujarati .D \& D. C. Porter (2009). Basics econometrics, New York: Mcgraw-Hill International Edition.

Huang, Tzu-long A., Hallan, Peter, F \& Peter, E. M. (1998). Empirical tests of efficiency wage models, Economica, 65, 125-43

Laurin, C. \& Y, Bozac (2000). Privatization and productivity improvement: the case of Canadian National (CN), working paper, Ecoles de HEC, montreal.

Lichtenberg, F. R. (1993). The output contributions of computer Equipment and personnel: a firm level analysis. National bureau of economic research working paper No 4540, Cambridge MA.

Marshall, A. (1890) Principles of Economics, London: Macmillan \& Co, 1-71.

Mccally, B. M. (1990). Demonstrated labour efficiency: an effective labour cost control and analytical tool. Cost engineering, 41(11), 33-37

Muhlan, P. \& Lindanberg, S. M. (2003). Efficiency wages: relationship between wage and commitment. Journal of management and government, 7, 385-400.

Papadogonas, T \& Voulgaris, F. (2005). Labour productivity growth in Greek manufacturing Firms, Operational research. 5(3), 459-472.

Stankevicene, A., liucvaitiene, A. \& Simelyte, A. (2009). The evaluation of labour efficiency and its impact on the development of long-term competitive ability: a case study of production of food and beverages in the Balti states. SCEE, 245-254.

Umoru, D. \& Yaqub, J. O. (2013). Labour productivity and health capital in Nigeria: the empirical evidence. International journal of humanities and social science, 3(4), 199-221 